\title{
Herbage yield, protein content, and carbohy- drate reserves in gulf cordgrass (Spartina spartinae)
}

\author{
ANDRES GARZA JR., TERRY MCLENDON, AND D. LYNN DRAWE
}

Atuhors are with Texas State Soil and Water Conservation Board, Falfurrias, Texas 78355; Range Science Dept., Colorado State Univ., Fort Collins 80523; and the Rob and Bessie Welder Wildlife Refuge, Sinton, Texas 78387.

\begin{abstract}
Gulf cordgrass (Spartina spartinae [Trin.] Merr.) is a highly productive bunchgrass that dominates thousands of hectares of marshlands along the Gulf coast. Herbage yield, protein content, and carbohydrate reserve patterns were studied for the species for 18 months on the Welder Wildlife Refuge on the central Texas coast. Plots were clipped at 1 -month intervals at 10 - and $20-\mathrm{cm}$ stubble heights. Herbage yield and protein content were greater for plants clipped at 10-cm stubble height as compared with those clipped at $20 \mathrm{~cm}$. Total nonstructural carbohydrate reserve levels in both stem bases and roots were also greater in plants clipped at the lower stubble height. Lowest carbohydrate reserve levels were recorded during periods of active growth. Results suggested that gulf cordgrass can withstand monthly removal of herbage to a height of $10 \mathrm{~cm}$ for a period of at least 18 months without adverse effects. The most sensitive periods for herbage removal, based on TNC and protein levels, were late summer and early fall.
\end{abstract}

Key Words: forage, management, marshlands, protein, Texas coast, TNC, total nonstructural carbohydrates, wetlands

Spartina marshes are common ecosystems along the Atlantic and Gulf coasts of the United States (Bertness 1991). Gulf cordgrass (Spartina spartinae [Trin.] Merr.) is a highly productive, native, warm-season, perennial bunchgrass that grows on several thousand hectares in the Gulf Prairies and Marshes region of Texas. Gulf cordgrass dominance in some areas is such that all other species are excluded (Oefinger and Scifres 1977). Though highly productive, mature gulf cordgrass is coarse and relatively unpalatable to grazing animals. Conversely, immature and succulent regrowth of gulf cordgrass is readily eaten by livestock, and removal of coarse stem and leaf material by either burning or mowing induces new growth which is more palatable and nutritious to livestock (Angell et al. 1986).

Intensive grazing management is required to increase the use of gulf cordgrass for livestock production while maintaining the resource. This type of grazing management would increase the time gulf cordgrass remained in an immature growth stage, while still maintaining long-term sustained forage production. Knowledge of herbage production, protein content, and carbohydrate reserve patterns is needed to develop appropriate grazing systems. Since this information was not available for gulf cordgrass, this study was designed to determine: (1) levels of nonstructural carbohydrates at various stages of growth and (2) effects of clipping at 2 stubble heights $(10$ and $20 \mathrm{~cm})$ on herbage yield, protein content, and nonstructural carbohydrate levels of this species.

\footnotetext{
The senior author was funded by a grant from the Rob and Bessie Welder Wildlife Foundation, Sinton, Texas. The authors also wish to thank Joe Trlica for his helpful comments on this manuscript.

Rob and Bessie Welder Wildlife Foundation Contribution No. 400.

Manuscript accepted 4 Jul. 1993.
}

\section{Study Area and Methods}

The study area was in a gulf cordgrass community (Drawe et al. 1978) on the Rob and Bessie Welder Wildlife Foundation Refuge, $11 \mathrm{~km}$ north of Sinton, on the central Texas coast. The soil on the site was a saline Aransas clay (Vertic Haplaquoll, fine, montmorillonitic, hyperthermic). Salinity ranged from 4 to $16 \mathrm{mmhos} / \mathrm{cm}$ (Guckian and Garcia 1973). Average annual rainfall is approximately $89 \mathrm{~cm}$ with long, hot summers and short, mild winters (Drawe et al. 1978). Extreme fluctuations in annual precipitation are common in this area, and precipitation was above average during most of this study (Fig. 1).

A 0.2-ha exclosure was constructed in the gulf cordgrass community 1 month prior to the beginning of the study to exclude grazing by cattle and deer. Eight $16-\mathrm{m}^{2}$ plots were randomly located in the exclosure with a buffer strip $(>1 \mathrm{~m})$ between plots. There were 3 treatments: (1) clipped to a $10-\mathrm{cm}$ stubble height each month, (2) clipped to a $20-\mathrm{cm}$ stubble height each month, and (3) unclipped (control). Two of the eight $16-\mathrm{m}^{2}$ plots were randomly assigned to the first treatment, 2 were assigned to the second treatment, and 4 were assigned to the third treatment. Three $1-\mathrm{m}^{2}$ subplots were randomly selected each month within each $16-\mathrm{m}^{2}$ plot for sampling herbage. Each subplot was clipped to the respective stubble height with hand clippers, and the phytomass placed in separate paper bags for analysis.

Roots were sampled by collecting $7.5-\mathrm{cm}$ diameter core sample to a depth of $20 \mathrm{~cm}$ from 3 randomly selected locations in each $16-\mathrm{m}^{2}$ plot. Immediately prior to core sampling, each sample location was clipped to a stubble height of $5 \mathrm{~cm}$. A $25-\mathrm{cm}$ core sample was collected for each subplot. Cores included the 5-cm crown (stem base) zone and $20 \mathrm{~cm}$ below the soil surface. Samples were washed over a screen upon removal from the core sampler to remove attached soil, put in plastic bags, and placed on ice in the field. These samples were placed in a freezer upon return to the laboratory. After herbage and root sampling were completed, the entire $16-\mathrm{m}^{2}$ treatment plot was clipped to the respective stubble height and the clipped material removed. Control plots remained unclipped throughout the study except for portions used to collect material for chemical analyses.

Herbage was dried at $41^{\circ} \mathrm{C}$ for 48 hours and weighed. The 3 samples from each plot were then composited ( 3 subsamples per replicate) and ground to pass through a 40-mesh screen. This sample was then analyzed for total nitrogen $(\mathrm{N})$ content by the micro-Kjeldahl method as modified by Hertel (1975). Crude protein was calculated by multiplying $\mathrm{N}$ content by 6.25 and reported on a dry-matter basis. Samples for carbohydrate analysis were dried at $70^{\circ} \mathrm{C}$ for 36 hours, separated as to basal stems $(0-5 \mathrm{~cm}$ above soil surface) or roots $(0-20 \mathrm{~cm}$ below soil surface), and ground separately to pass through a 40-mesh screen. Total nonstructural carbohydrate (TNC) determinations utilized a diastase enzyme solution to hydrolyze starch and disaccharides to mono- 


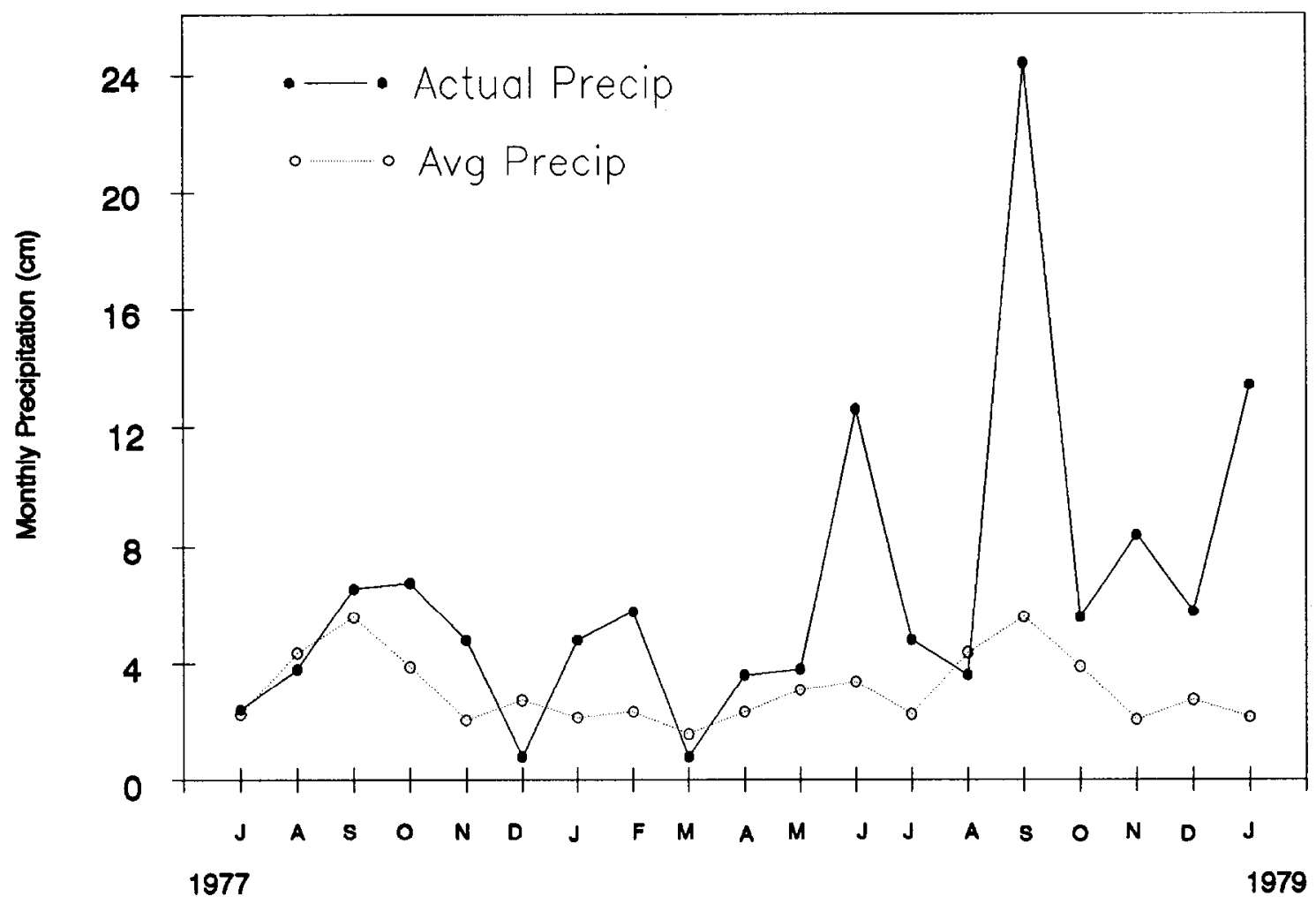

Fig. 1. Monthly precipitation (cm) during the study period compared with 30-year monthly precipitation means (cm) on the Welder Wildlife Refuge.

mers (Smith 1969). Reducing power was measured by the ShaefferSomogyi copperiodemetric titration method (Smith 1969). Total nonstructural carbohydrate determinations were reported as percentages on a dry matter basis using a glucose standard.

To adjust herbage yield for differences in number of days within a growth period, the monthly yield value for each plot was divided by the number of days since the last clipping to arrive at an average daily yield value. Treatment effects on average daily yield, protein concentration, herbage TNC, and root TNC were analyzed by using ANOVA (randomized complete block design) to test for significant differences $(P<0.05)$. Tukey's test was used to determine significant differences $(P<0.05)$ among means.

\section{Results and Discussion}

\section{Herbage Yield}

Average daily herbage yield increased during spring and decreased during summer, fall, and mid-winter, except for a period of increased productivity during September (Fig. 2A). Summers in South Texas are typically hot and dry with the upper profiles of cordgrass-dominated wet soils often drying out during July and August. September is typically a rainy month, the result of tropical storms and the first cool fronts of the season. Gulf cordgrass productivity was lowest from December to February, the coldest season in South Texas. Average herbage yield of this cordgrass community averaged approximately $1.6 \mathrm{~g} \mathrm{~m}^{-2} \mathrm{~d}^{-2}$ (Fig. 2A). This rate is comparable to those reported for other salt marsh-Spartina communities (Odum 1971, Whittaker 1975, Bertness 1991) and flood-plain sacaton grasslands (Haferkamp 1982, Cox 1985), and is approximately $7 \%$ of the extremely productive Echinochloa communities of the Amazon floodplain (Piedade et al. 1991).

Herbage growth on plots clipped to $10 \mathrm{~cm}$ was greater (overall mean of $1.51 \mathrm{~g} \mathrm{~m}^{-2} \mathrm{~d}^{-1}$ ) than on plots clipped to $20 \mathrm{~cm}$ (overall mean of $0.94 \mathrm{~g} \mathrm{~m}^{-2} \mathrm{~d}^{-1}$, Fig. 2A). This was expected since foliage density increases greatly near the crown in bunchgrasses such as gulf cordgrass. Although clipping height affected herbage yield $(P<0.01)$, it did not affect the pattern of herbage yield except for 1 sampling period (May 78).

\section{Protein Content}

Crude protein content of gulf cordgrass herbage varied between $8 \%$ and $10 \%$ throughout most of the year, with a sharp decline during dry summers months (Fig. 2B). In southern Arizona, Cox (1985) reported a similar decrease in $\mathrm{N}$ content of big sacaton (Sporobolus wrightii Munro) during summer, which was the period of highest herbage production. However, unlike in Arizona, summer in our study was a period of low productivity. Low protein content in our study may have been the result of decreased availability of $\mathrm{N}$ to the plant because of low soil moisture. The plant tissue analyzed for protein content was not old growth material left from early spring growth, but was new growth from the period since the last clipping because the entire $16-\mathrm{m}^{2}$ treatment plots were clipped at the end of each monthly sampling period. Therefore the low protein content may have been caused by lower $\mathrm{N}$ availability during tissue growth and not maturity level of the herbage as reported for big sacaton in South Texas during the same period (Haferkamp 1982). High protein values for winter months probably resulted from greater $\mathbf{N}$ availability during periods of limited growth. Soil moisture was abundant during fall and winter, and soil $\mathrm{N}$ levels should have been relatively high as a result of decomposition and mineralization (Sharrow and Wright 1977, Cox 1985) and nutrient transport onto the site in surface runoff from fall rains (Cox 1985). Such conditions would result in high availability of $N$ and, with the low to medium herbage yield values caused by cool weather, relatively low levels of tissue carbon (C). Hence, a low $\mathrm{C}: \mathrm{N}$ ratio and high crude protein content was expected.

Crude protein content was not significantly $(P>0.05)$ affected by clipping height early in the study, but was higher in plants clipped to $10 \mathrm{~cm}$ than in plants clipped to $20 \mathrm{~cm}$ during 6 of the last 8 months (Fig. 2B). This may also have been caused by low tissue production during a period of abundant soil $\mathrm{N}$. Herbage yield during the dry summer was higher for plants clipped at the $10-\mathrm{cm}$ clipping intensity than for plants clipped at $20 \mathrm{~cm}$. Increased herbage production has been correlated with increased root pro- 

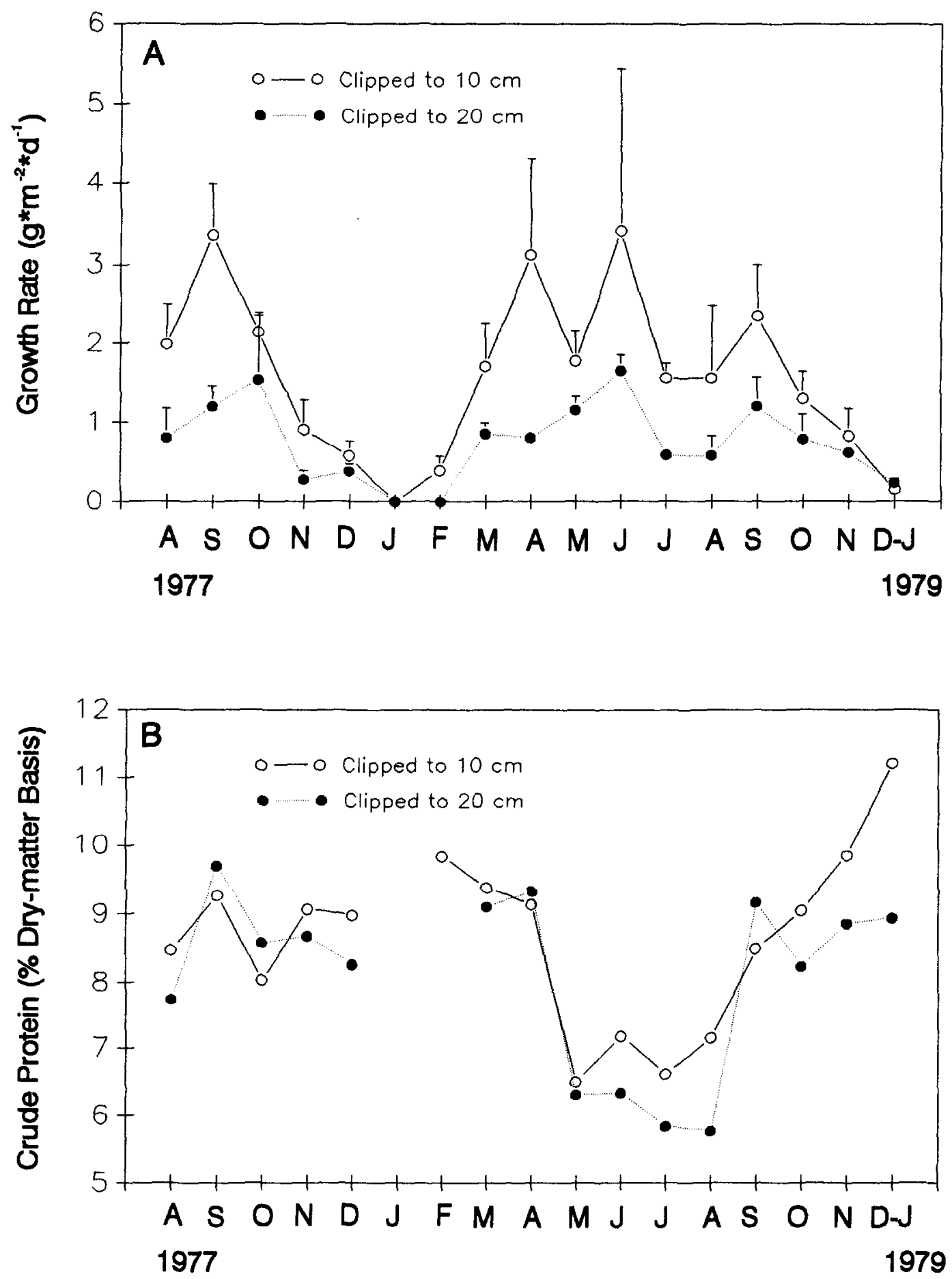

Fig. 2. Growth rate ( $\mathrm{g} \mathrm{m}^{-2} \mathrm{~d}^{-1}$ dry-weight herbage biomass) (A) and crude protein concentration (\%, dry-weight basis) (b) of gulf cordgrass clipped monthly at 10- and $20-\mathrm{cm}$ stubble heights on the Welder Wildlife Refuge. Bars indicate $95 \%$ confidence intervals of the means.

duction in a number of species (Painter and Detling 1981, Richards 1984, Wan and Sosebee 1990, Redente et al. 1992). If increased aboveground production for plants clipped at the $10-\mathrm{cm}$ intensity also resulted in increased belowground production in our study, the more extensive root systems may have given the more intensively clipped plants greater access to moisture and $\mathrm{N}$ supplies (Gleeson and Tilman 1990, Wedin and Tilman 1990). Roots of clipped plants may also be more efficient in $\mathrm{N}$ uptake than roots of unclipped plants (Polley and Detling 1989).

\section{Stem Carbohydrate Reserves}

Total nonstructural carbohydrate content in stem bases of gulf cordgrass on unclipped plots varied from 4.4 to $8.2 \%$, with most values between 6.5 and $7.3 \%$ (Fig. 3). There was a pronounced decrease in TNC content during late summer or early fall which corresponded to the period of fall regrowth. A similar decrease in TNC reserves following growth initiation after quiescence or dormancy has been reported for other grass species (Daer and Willard 1981, Menke and Trlica 1981, Stout et al. 1983, Krueger and Bedunah 1988, Orodho and Trlica 1990). Overall, clipping to either 10 - or $20-\mathrm{cm}$ heights resulted in decreased $(P<0.05)$ mean TNC concentration in stem bases compared with unclipped plots. There were no differences among plants clipped at either the $10-$ or $20-\mathrm{cm}$ stubble height. A similar relationship between crown TNC and clipping intensity has been reported for tall fescue (Festuca arundinacea Schreb.) (Bahrani et al. 1983) and Indian ricegrass (Oryzopsis hymenoides Roem. \& Schult.) (Orodho and Trlica 1990). 


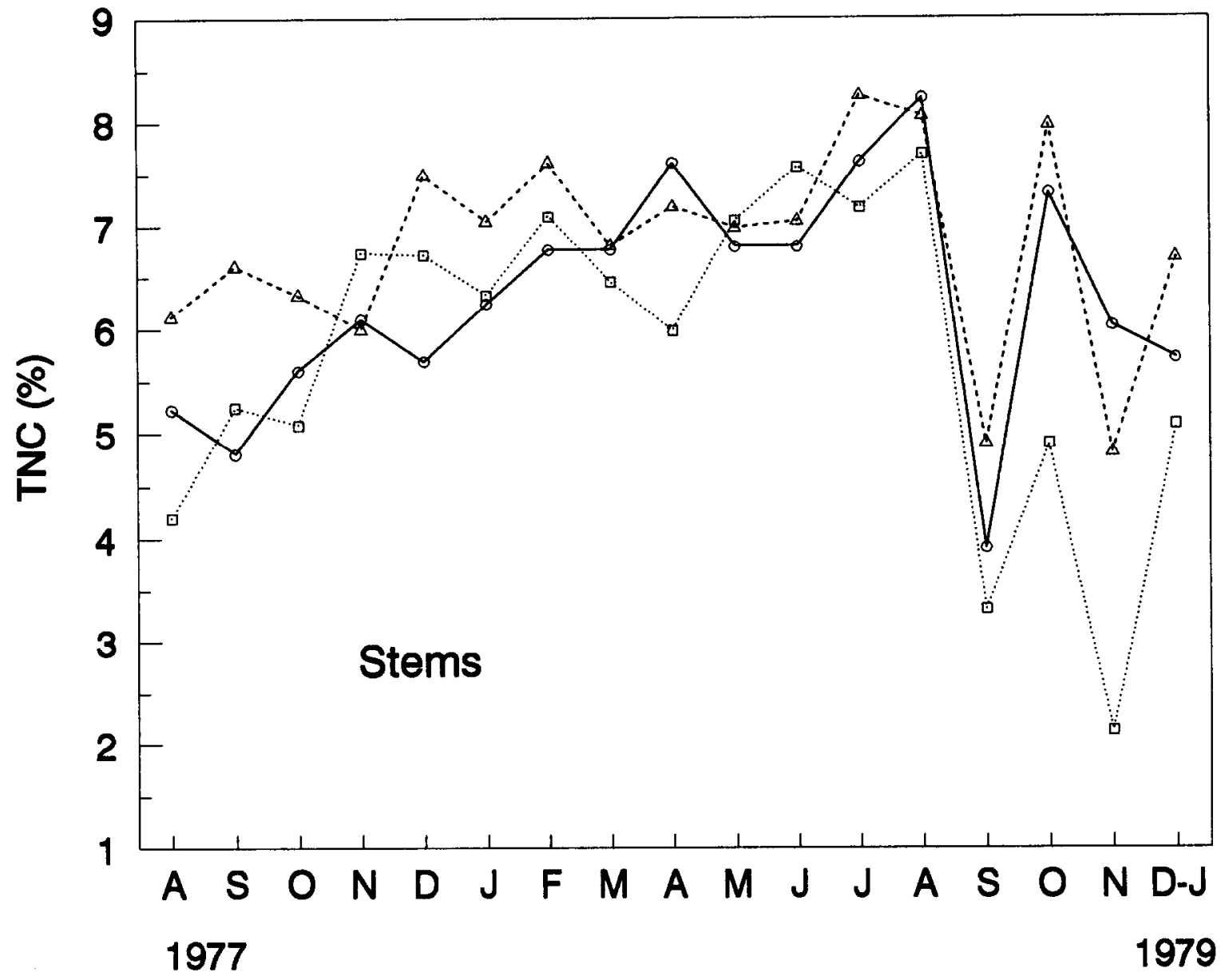

Clipped to $20 \mathrm{~cm}$

Clipped to $10 \mathrm{~cm}$

Control

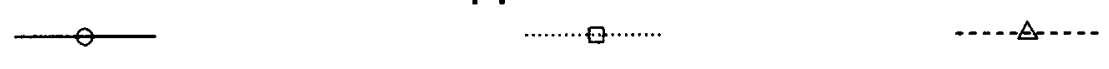

Fig. 3. Total nonstructural carbohydrate concentration (\%) in basal stems of gulf cordgrass plants clipped monthly at 10-and 20-cm stubble heights on the Welder Wildlife Refuge.

The greatest differences in TNC content between clipped and unclipped gulf cordgrass plants occurred at the beginning and end of the study (Fig. 3). Initial clipping resulted in a decrease in TNC content of stem bases for 3 months. Although these plants continued to be clipped at monthly intervals, TNC content increased to approximate unclipped levels within 3 to 6 months and remained near unclipped levels until the final 2 months of the study. These results indicated that clipping gulf cordgrass resulted in a rapid decrease in stem TNC immediately following clipping. Decreased stem base TNC may have resulted from utilization of reserves to initiate regrowth or maintain roots. A new equilibrium was reached after 3-6 months and TNC reserve levels returned to near unclipped plant levels. However, after 12-14 months of monthly clipping to $10 \mathrm{~cm}$, TNC levels again decreased as compared with unclipped plants. This may be an indication of accumulated stress within plants clipped at this frequency and intensity. Menke and Trlica (1983) also reported that multiple defoliations of resistant species eventually caused reductions in TNC storage.

\section{Root Carbohydrate Reserves}

Total nonstructural carbohydrate levels of gulf cordgrass roots were lower than those for basal stems. The TNC levels of unclipped plants decreased during periods of high herbage production and increased during periods of low herbage production (Fig. 4). This pattern would be expected if stored TNC were utilized to initiate production of new herbage (Krueger and Bedunah 1988, Orodho and Trlica 1990, Wan and Sosebee 1990, Dyer et al. 1991) or roots (Wilson 1984). Once the production rate of new growth decreased, TNC supplies were replenished from surplus photosynthates from mature leaves (Steele et al. 1984, Harrington 1989).

Clipping reduced $(P<0.05)$ average root TNC content, although there were no differences $(P>0.05)$ among plants from the 2 clipping height treatments. Root TNC content of clipped gulf cordgrass plants, like basal stem TNC content, was lower than control plant levels during the initial 3 to 6 months of the study, then approached the unclipped levels thereafter. Similarly, Krueger and Bedunah (1988) found that rhizome TNC levels in pinegrass (Calamagrostis rubescens Buckl.) were reduced by clipping for 2 to 4 weeks and, in general, there was no difference among plants from 5- and 10-cm clipping heights. Unlike stem TNC content, root TNC content of gulf cordgrass remained near the levels of unclipped plants late in our study.

\section{Management Implications}

These results indicated that gulf cordgrass could withstand monthly herbage removal to a height of $10 \mathrm{~cm}$ for 18 months under 


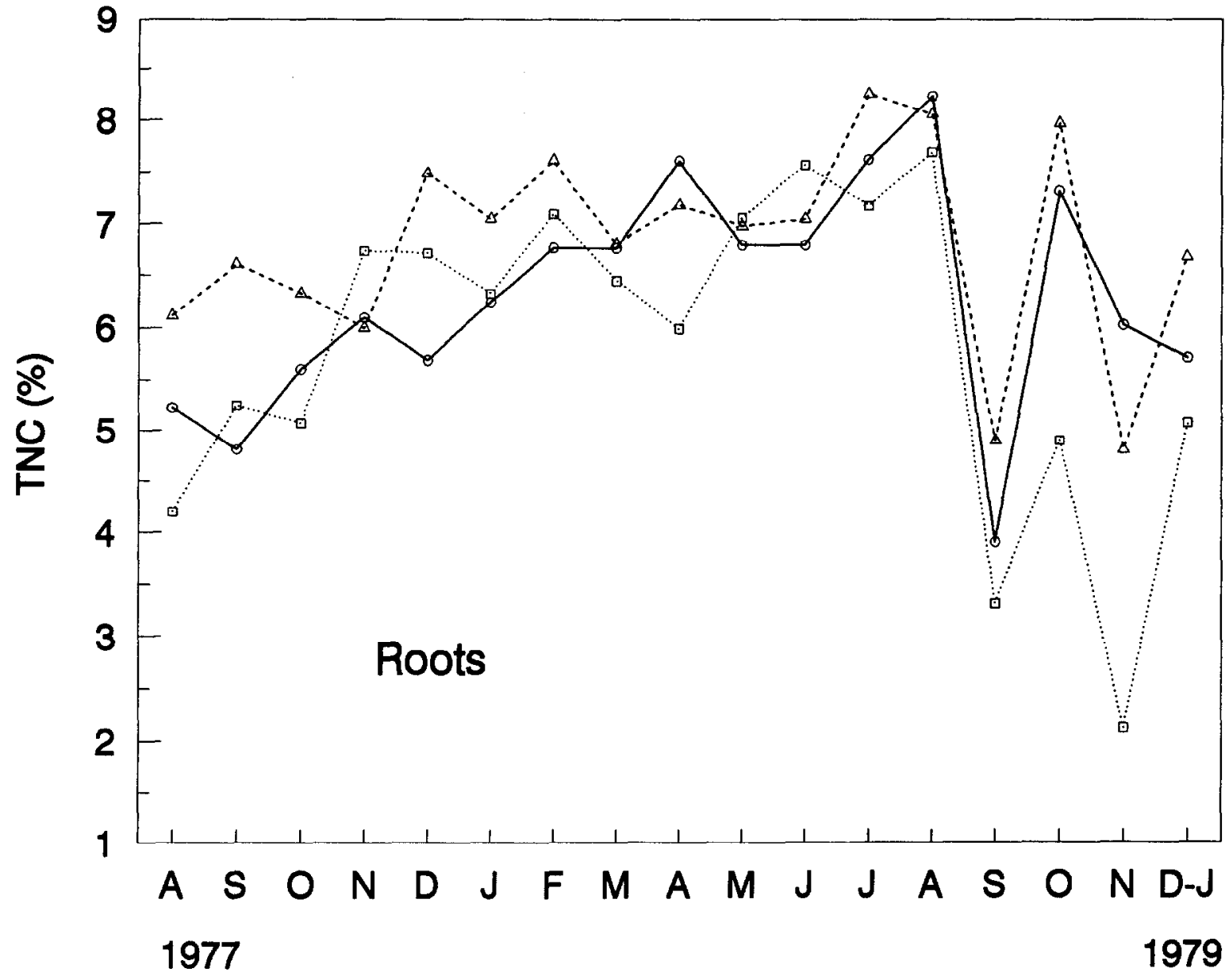

\section{Clipped to $20 \mathrm{~cm}$}

\section{Clipped to $10 \mathrm{~cm}$}

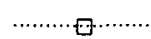

\section{Control}

Fig. 4. Total nonstructural carbohydrate concentration (\%) in roots (0-20-cm depth) of gulf cordgrass plants clipped monthly at 10- and $20-\mathrm{cm}$ stubble heights on the Welder Wildlife Refuge.

the above-average rainfall conditions that occurred during this study. Clipping to a $20-\mathrm{cm}$ height resulted in lower herbage yield and crude protein content than clipping at $10 \mathrm{~cm}$, and did not result in higher TNC levels. Most sensitive periods for herbage removal, based on TNC levels, were late summer and early fall when plants were in a period of regrowth following drought dormancy. Total nonstructural carbohydrate storage levels were low and leaf $\mathrm{N}$ content was high, so plants might be stressed by herbage removal during these periods.

Currently, there is disagreement among researchers as to the importance of TNC reserves in the process of recovery from defoliation. Richards and Caldwell (1985) found that differences in regrowth in Agropyron desertorum (Fisch.) Schult. and A. spicatum Scribn. \& Smith following defoliation were not correlated with TNC concentrations. Instead, they found that the majority of carbon used in regrowth comes from current photosynthate production rather than from stored carbon reserves, although this varied somewhat by species (Richards and Caldwell 1985:918). Busso et al. (1990) supported these conclusions relative to these 2 cool-season grasses, except following drought-induced stress. Other researchers (Chung and Trlica 1980, Daer and Willard 1981, Menke and Trlica 1981, Bahrani et al. 1983, Stout et al. 1983 Krueger and Bedunah 1988, Orodho and Trlica 1990, Wan and Sosebee 1990) suggest that TNC reserves are important during the regrowth process, at least initially. Our results indicated that initiation of regrowth following defoliation and level of TNC reserves in gulf cordgrass were related. We do not suggest that all the photosynthates utilized in regrowth come from stored reserves, nor do we attempt to identify the immediate source of these photosynthates. Rather, our purpose was to use TNC levels as an indicator of stress dynamics in the plant (Daer and Willard 1981, Menke and Trlica 1983, Kalmbacher et al. 1983, Wan and Sosebee 1990). The decrease in TNC reserves immediately following defoliation and the low levels for 3 months afterward suggest that the plants were stressed (not necessarily detrimentally). The fact that TNC reserves eventually returned to unclipped plant levels suggests an end to the stress period, as a surplus of photosynthates was probably available for storage.

Gulf cordgrass has high forage and protein production potential for use when grazing animals are normally under nutritional stress and when utilized in a flexible rotation grazing program. The study community produced $5,270 \mathrm{~kg} \mathrm{ha}^{-1}$ of dry-weight phytomass and $421 \mathrm{~kg} \mathrm{ha}^{-1}$ of crude protein per year when clipped monthly to a $10-\mathrm{cm}$ height, compared with $5,430 \mathrm{~kg} \mathrm{ha}^{-1}$ of phytomass and 222 $\mathrm{kg} \mathrm{ha}^{-1}$ of crude protein on unclipped plots.

We present a possible grazing management regime for gulf cordgrass based on results from this study and previous studies. Although this provisional regime is based on experimental results, 
some speculative aspects remain that have not been subjected to experimentation. Therefore some uncertainty will be associated with the regime until these aspects have been adequately tested.

Fire can be used to remove old growth and stimulate production of new growth in late summer or early fall, depending on moisture conditions. Burning should be timed to occur as closely as possible to the period between summer drought and fall rains, but soil moisture should be adequate following burning to ensure that the plants are not under moisture stress, and should take place before fall regrowth has progressed significantly. Grazing should be deferred for 45-90 days following burning to allow TNC levels to be replenished. This should allow for a standing crop $(10-\mathrm{cm}$ stubble height) of $1,500-2,000 \mathrm{~kg} \mathrm{ha}^{-1}$ of $8.5-9.0 \%$ crude protein forage by November when other native warm-season species begin to go dormant. Grazing intensity should be such that stubble height is maintained between 10 and $20 \mathrm{~cm}$, and grazing could continue through March. Calving season on most Texas coastal ranches is generally December through March. During this period, gulf cordgrass would contribute an additional $500-1,000 \mathrm{~kg} \mathrm{ha}^{-1}$ of 9.1-9.6\% crude protein herbage. Angell et al. (1986) found that forage consumed by cattle during winter and early spring on fallburned gulf cordgrass pastures contained $43 \%$ higher crude protein and was $8 \%$ more digestible than forage consumed on unburned gulf cordgrass pastures. In April, livestock should be moved off the gulf cordgrass to allow it to replenish TNC levels during spring and summer.

The grazing regime of gulf cordgrass should also provide additional range benefits. Other native pastures could be deferred during early spring, allowing cool-season species to mature and warm-season species to begin spring growth without the heavy grazing pressure associated with traditional grazing programs. February and March are months when grazing of poisonous plants by cattle is most serious in the region, the result of animals seeking early green forage. Poisonous plants are not a problem on cordgrass sites, and are seldom a serious problem in the region after early spring. Cordgrass communities are also used by white-tailed deer (Odocoileus virginianus Bod.) for fawning and bedding grounds. Fawning generally begins in early May and continues through mid July, with fawns relatively sedentary through June. Burning in late summer or early fall, rather than the traditional February burning, and minimal use by livestock during late spring and summer, should increase the value of gulf cordgrass communities as wildlife habitat.

\section{Literature Cited}

Angell, R.F., J.W. Stuth, and D.L. Drawe. 1986. Diets and live-weight changes of cattle grazing fall burned gulf cordgrass. J. Range Manage. 39:233-236.

Bahrani, J., E.R. Beaty, and K.H. Tan. 1983. Relationship between carbohydrate, nitrogen contents, and regrowth of tall fescue tillers. J. Range Manage. 36:234-235.

Bertness, M.D. 1991. Zonation of Spartina patens, and Spartina alterniflora in a New England salt marsh. Ecology 72:138-148.

Busso, C.A., J.H. Richards, and N.J. Chatterton. 1990. Nonstructura carbohydrates and spring regrowth of two cool-season grasses: interaction of drought and clipping. J. Range Manage. 43:336-343.

Chung, Hsu-Ho, and M.J. Trlica. 1980. ${ }^{14} \mathrm{C}$ distribution and utilization in blue grama as affected by temperature, water potential and defoliation regimes. Oecologia 47:190-195.

Cox, J.R. 1985. Above-ground biomass and nitrogen quantities in a big sacaton (Sporobolus wrightii) grassland. J. Range Manage. 38:273-276.

Daer, T., and E.E. Willard. 1981. Total nonstructural carbohydrate trends in bluebunch wheatgrass related to growth and phenology. J. Range Manage. 34:377-379.

Drawe, D.L., A.D. Chamrad, and T.W. Box. 1978. Plant communities of the Welder Wildlife Refuge. Welder Wildlife Foundation, Sinton, Texas, Contribution 5, Series B. (revised).
Dyer, M.I., M.A. Acra, G.M. Wang, D.C. Coleman, D.W. Freckman, S.J. McNaughton, and B.R. Strain. 1991. Source-sink carbon relations in two Panicum coloratum ecotypes in response to herbivory. Ecology 72:1472-1483.

Gleeson, S.K., and D. Tilman. 1990. Allocation and the transient dynamics of succession on poor soils. Ecology 71:1144-1155.

Guckian, W.J., and R.N. Garcia. 1973. Soil Survey Handbook: Aransas and San Patricio Counties. USDA Soil Conservation Service.

Haferkamp, M.R. 1982. Defoliation impacts on quality and quantity of forage harvested from big sacaton (Sporobolus wrightii Munro). J. Range Manage. 35:26-31.

Harrington, M.G. 1989. Gambel oak root carbohydrate response to spring, summer, and fall prescribed burning. J. Rangc Manage. 42:504-507.

Hertel, J. 1975. Laboratory determination of protein. Texas A\&I Univ. Forage Testing Laboratory Mimeo

Kalmbacher, R.S., K.J. Boote, and F.G. Martin. 1983. Burning and 2,4,5-T application on mortality and carbohydrate reserves in saw-palmetto. $\mathrm{J}$. Range Manage. 36:9-12.

Krueger, J.K., and D.J. Bedunah. 1988. Influence of forest site on total nonstructural carbohydrate levels of pinegrass, elk sedge, and snowberry. J. Range Manage. 41:144-149.

Menke, J.W., and M.J. Trlica. 1981. Carbohydrate reserve, phenology, and growth cycles of nine Colorado range species. J. Range Manage. $34: 269-277$.

Menke, J.W., and M.J. Trlica. 1983. Effects of single and sequential defoliations on the carbohydrate reserves of four range species. J. Range Manage. 36:70-74

Odum, E.P. 1971. Fundamentals of ecology. 3rd Edition. W.B. Saunders. Philadelphia.

Oefinger, R.D., and C.J. Scifres. 1977. Gulf cordgrass production, utilization, and nutritional value following burning. Texas Agr. Exp. Sta. B-1176.

Orodho, A.B., and M.J. Trlica. 1990. Clipping and long-term grazing effects on biomass and carbohydrate reserves of Indian ricegrass. $\mathrm{J}$. Range Manage. 43:52-57.

Painter, E.L., and J.K. Detling. 1981. Effects of defoliation on net photosynthesis and regrowth of western wheatgrass. J. Range Manage. 34:68-71.

Piedade, M.T.F., W.J. Junk, and S.P. Long. 1991. The productivity of the $\mathrm{C}_{4}$ grass Echinochloa polystachya on the Amazon floodplain. Ecology 72:1456-1463.

Polley, H.W., and J.K. Detling. 1989. Defoliation, nitrogen, and competition: effects on plant growth and nitrogen nutrition. Ecology 70:721-727.

Redente, E.F., J.E. Friedlander, and T. McLendon. 1992. Response of early and late semiarid successional species to nitrogen and phosphorus gradients. Plant and Soil 140:127-135.

Richards, J.H. 1984. Root growth response to defoliation in two Agropyron bunchgrasses: field observations with an improved root periscope. Oecologia 64:21-25.

Richards, J.H., and M.M. Caldwell. 1985. Soluble carbohydrates, concurrent photosynthesis and efficiency in regrowth following defoliation: a field study with Agropyron species. J. Applied Ecol. 22:907-920.

Sharrow, S.H., and H.A. Wright. 1977. Proper burning intervals for tobosagrass in West Texas based on nitrogen dynamics. J. Range Manage. 30:343-346.

Smith, D. 1969. Removing and analyzing total nonstructural carbohydrates from plant tissue. Wisconsin. Agr. Exp. Sta. Rep. 41

Steele, J.M., R.D. Ratliff, and G.L. Ritenour. 1984. Seasonal variation in total nonstructural carbohydrate levels in Nebraska sedge. J. Range Manage. 37:465-467.

Stout, D.G., M. Suzuki, and B. Brooke. 1983. Nonstructural carbohydrate and crude protein in pinegrass storage tissues. J. Range Manage. 36:440-443.

Wan, C., and R.E. Sosebee. 1990. Relationship or photosynthetic rate and edaphic factors to root carbohydrate trends in honey mesquite. J. Range Manage. 43:171-176.

Wedin, D.A., and D. Tilman. 1990. Species effects on nitrogen cycling: a test with perennial grasses. Oecologia 84:433-441.

Whittaker, R.H. 1975. Communities and ecosystems. 2nd Edition. Macmillan Co., N.Y.

Wilson, A.M. 1984. Nonstructural carbohydrates and root development in blue grama seedlings. J. Range Manage. 37:28-30. 